\title{
SISTEM PENDUKUNG KEPUTUSAN PEMILIHAN SUPPLIER KAIN DENGAN METODE MOORA
}

\author{
Sandyea Proboningrum ${ }^{1}$, Acihmah Sidauruk ${ }^{2}$ \\ 1) Sistem Informasi Universitas AMIKOM Yogyakarta \\ 2) Pascasarjana MTI STIMIK AMIKOM Yogyakarta \\ Jl Ringroad Utara, Condongcatur, Depok, Sleman, Yogyakarta Indonesia 55283 \\ ${ }^{1}$ sandyea.p@students.amikom.ac.id \\ 2 acihmah@amikom.ac.id
}

\begin{abstract}
Abstrak - Sistem pendukung merupakan cara yang dapat digunakan untuk membantu seseorang maupun perusahaan dalam mengambil keputusan. Salah satunya yaitu pengambilan keputusan dalam pemilihan supplier kain. Pemilihan supplier merupakan salah satu bagian terpenting dalam suatu usaha. Untuk mendapatkan hasil yang maksimal, dibutuhkan supplier yang terbaik dan berkualitas. Karena banyaknya supplier kain, Yani kain kesulitan dalam memilih supplier dengan kelebihannya masing-masing. Metode yang digunakan dalam pengambilan keputusan supplier kain pada Yani kain adalah dengan menggunakan metode Multi-Objective Optimazion on the basis of Ratio Analysisi (MOORA). Pada penelitian ini terdapat 5 kriteria yang ada, yaitu desain, harga, kualitas, pengiriman dan pelayanan. Setelah dilakukan perhitungan terhadap 30 sample data supplier, dilakukan pengujian menggunakan confusion matrix dengan hasil akurasi sebesar $80 \%$. Untuk implementasi aplikasi dibangun berbasis web.
\end{abstract}

Kata kunci : MOORA, Sistem Pendukung Keputusan, Supplier, Web, Confusion Matrix.

\section{Pendahuluan}

Pengambilan keputusan merupakan suatu hal yang sangat berpengaruh dalam proses menghadapi alternatif yang dipilih. Pada masa ini dalam mengambil keputusan sudah tidak lagi hanya dengan akal manusia. Keterbatasan manusia dalam berpikir untuk memecahkan suatu permasalahan kini dapat dibantu dengan komputerisasi. Penggunaan komputer telah berkembang dari sekedar pengolahan data ataupun penyaji informasi, menjadi mampu untuk menyediakan pilihan-pilihan sebagai pendukung pengambil keputusan. Perkembangan teknologi informasi telah memungkinkan pengambil keputusan dapat dilakukan dengan lebih cepat dan cermat.

Supplier merupakan mitra bisnis yang memegang peranan sangat penting dalam menjamin ketersediaan barang pasokan yang dibutuhkan. Kinerja supplier akan mempengaruhi performansi atau kinerja perusahaan. Oleh karena itu, perusahaan perlu menilai supplier secara cermat dan tepat. Yani Kain sendiri merupakan toko yang bergerak dibidang tekstil. Yani Kain tidak memproduksi sendiri kain yang dijual melainkan harus mencari supplier atau pemasok lain yang memiliki stok kain yang sesuai dengan permintaan. Terdapat kelemahan dalam pemilihan pemasok yang dilakukan oleh Yani Kain yaitu pengambil keputusan menilai hanya berdasarkan pada harga yang ditawarkan dan kualitas yang dimiliki barang secara subjektif.

Dari permasalahan yang telah dijabarkan maka untuk membantu Yani kain dalam memilih supplier serta untuk menghindari proses pemilihan supplier mengandalkan intuisi (subjektif) dibutuhkan sebuah rancang bangun sistem pendukung keputusan. Sistem pendukung keputusan pemilihan supplier ini mempertimbangkan dari beberapa kriteria-kriteria diantaranya, desain, harga, waktu pengiriman, kualitas, dan pelayanan.

Salah satu metode yang dapat digunakan untuk pemilihan supplier atau pemasok adalah dengan menggunakan metode MOORA. Metode MOORA sangat sederhana, stabil, dan kuat. Selain itu metode ini juga memiliki hasil yang lebih akurat dan tepat sasaran dalam membantu pengambilan keputusan. Bila dibandingkan dengan metode lain metode MOORA lebih sederhana dan mudah diimplementasikan.

\section{Metodologi Penelitian}

\section{A. Teknik Pengumpulan Data}

Agar memperoleh data yang relevan diperlukan metodemetode dalam hal mengumpulkan data. Beberapa data yang digunakan yaitu: 


\section{Metode Observasi}

Yakni teknik atau pendekatan untuk mendapatkan data primer dengan cara mengamati langsung pada objek datanya.

\section{Metode Wawancara}

Teknik mengumpulkan data dengan cara melakukan interaksi tanya jawab langsung terhadap pihak yang bersangkutan dalam proses pembuatan sistem pendukung keputusan pemilihan supplier.

\section{B. Pengembangan Sistem}

Metode air terjun atau sering disebut metode waterfall sering dinamakan siklus hidup klasik(Classic life cycle), dimana hal ini menggambarkan pendekatan yang sistematis dan juga berurutan pada pengembangan perangkat lunak, dimulai dengan spesifikasi kebutuhan pengguna lalu berlanjut melalui tahapan-tahapan perencanaan (planning), pemodelan (modeling), konstruksi (construction), serta penyerahan system ke para pengguna (deployment), yang di akhir pada dukungan perangkat lunak lengkap yang dihasilkan(Pressman, 2012). Tahapan metode waterfall dapat dilihat pada gambar dibawah ini.

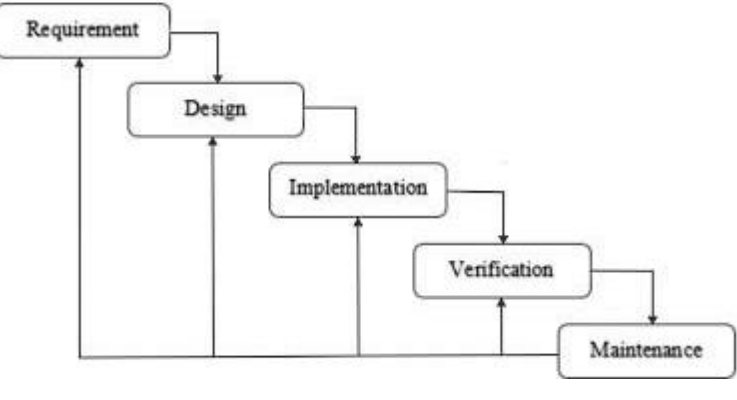

Gambar 1 Tahapan Metode Waterfall

Tahapan-tahapan dari metode waterfall adalah sebagai berikut:

\section{Requirement}

Tahap ini pengembang sistem diperlukan komunikasi yang bertujuan untuk memahami perangkat lunak yang diharapkan oleh pengguna dan batasan perangkat lunak tersebut. Informasi ini biasanya dapat diperoleh melalui wawancara, diskusi atau survei langsung. Informasi dianalisis untuk mendapatkan data yang dibutuhkan oleh pengguna.

2. System Design

Spesifikasi kebutuhan dari tahap sebelumnya akan dipelajari dalam fase ini dan desain sistem disiapkan. Desain Sistem membantu dalam menentukan perangkat keras(hardware) dan sistem persyaratan dan juga membantu dalam mendefinisikan arsitektur sistem secara keseluruhan.

\section{Implementation}

Pada tahap ini, sistem pertama kali dikembangkan di program kecil yang disebut unit, yang terintegrasi dalam tahap selanjutnya. Setiap unit dikembangkan dan diuji untuk fungsionalitas yang disebut sebagai unit testing.

\section{Integration \& Testing}

Seluruh unit yang dikembangkan dalam tahap implementasi diintegrasikan ke dalam sistem setelah pengujian yang dilakukan masing-masing unit. Setelah integrasi seluruh sistem diuji untuk mengecek setiap kegagalan maupun kesalahan.

\section{Operation \& Maintenance}

Tahap akhir dalam model waterfall. Perangkat lunak yang sudah jadi, dijalankan serta dilakukan pemeliharaan. Pemeliharaan termasuk dalam memperbaiki kesalahan yang tidak ditemukan pada langkah sebelumnya. Perbaikan implementasi unit sistem dan peningkatan jasa sistem sebagai kebutuhan baru.

\section{Metode MOORA}

Metode Multi-Objective Optimization by Ratio Analysis ( MOORA) adalah metode yang diperkenalkan oleh Brauers dan Zavadskas (2006). Metode yang relatif baru ini pertama kali digunakan oleh Brauers dalam suatu pengambilan dengan multi-kriteria[9]. Metode MOORA memiliki tingkat fleksibilitas dan kemudahan untuk dipahami dalam memisahkan bagian subjektif dari suatu proses evaluasi kedalam kriteria bobot keputusan dengan beberapa atribut pengambilan keputusan (Mandal dan Sarkar, 2012). Metode ini memiliki tingkat selektifitas yang baik karena dapat menentukan tujuan dari kriteria yang bertentangan. Dimana kriteria dapat bernilai menguntungkan (benefit) atau yang tidak menguntungkan (cost).

Metode MOORA terdiri dari lima langkah utama sebagai berikut :

Langkah 1: langkah pertama adalah menentukan tujuan dan mengidentifikasi atribut evaluasi yang bersangkutan.

Langkah 2: langkah selanjutnya menampilkan semua informasi yang tersedia untuk atribut dalam bentuk matriks keputusan. $\mathrm{x}$ adalah nilai kriteria masing-masing kriteria yang direpresentasikan sebagai matriks.

$$
\mathrm{X}=\left[\begin{array}{cccc}
\mathrm{X}_{11} & \mathrm{X}_{12} & \cdot & \mathrm{X}_{1 \mathrm{n}} \\
\mathrm{X}_{21} & \mathrm{X}_{22} & \cdot & \mathrm{X}_{2 \mathrm{n}} \\
\cdot & \cdot & \cdot & \cdot \\
\mathrm{X}_{\mathrm{m} 1} & \mathrm{X}_{\mathrm{m} 2} & \cdot & \mathrm{X}_{\mathrm{mn}}
\end{array}\right]
$$

Langkah 3: Brauers et al. (2008) menyimpulkan bahwa denominator, pilihan terbaik dari akar kuadrat dari penjumlahan kuadrat dari setiap alternatif per atribut. Rasio ini dapat dinyatakan sebagai berikut.

$$
x_{i j}^{*}=\frac{x_{i j}}{\sqrt{\sum_{i=1}^{m} X_{i j}^{2}}}
$$


Rasio $X_{\mathrm{ij}}$ menunjukkan urutan ke i dari alternatif pada kriteria ke j, m menunjukkan banyaknya jumlah alternatif dan n menunjukkan jumlah kriteria. Brauers et al. (2008) menyimpulkan bahwa untuk denominator, pilihan terbaik dari akar kuadrat dari penjumlahan kuadrat dari setiap alternatif per kriteria.

Langkah 4: untuk multi-objective optimization, hasil normalisasi adalah penjumlahan dalam hal pemaksimalan (dari atribut yang menguntungkan/benefit) dan pengurangan dalam hal peminimalan (dari atribut yang tidak menguntungkan/ cost). Selanjutnya masalah optimasi menjadi:

$$
Y_{i}=\sum_{j=1}^{g} x_{i j}-\sum_{j=g+1}^{n} x_{i j}
$$

Dimana g adalah nilai kriteria yang akan dimaksimalkan, (n-g) adalah nilai dari kriteria yang diminimalkan, dan $\mathrm{Y}_{\mathrm{i}}$ adalah nilai dari penilaian normalisasi alternatif $i$ terhadap semua atribut. Dalam beberapa kasus, sering mengamati beberapa kriteria yang lebih penting lainnya. memesan untuk memberikan lebih penting atribut, itu tersebut dilakukan dengan bobot yang sesuai (signifikan koefesien). Ketika bobot kriteria ini dipertimbangkan maka persamaan $\mathrm{Y}_{\mathrm{i}}$ adalah berikut

$$
Y_{i}=\sum_{j=1}^{g} w_{j} x_{i j}-\sum_{j=g+1}^{n} w_{j} x_{i j}
$$

Dimana $\mathrm{W}_{\mathrm{j}}$ adalah bobot atribut $\mathrm{j}$.

Langkah 5: Nilai $Y_{i}$ bisa Positif atau negatif tergantung dari jumlah maksimal (kriteria yang menguntungkan) dan minimal (kriteria yang tidak menguntungkan) dalam matriks keputusan.

\section{Confusion Matrix}

Confusion matrix merupakan pegujian yang dapat digunakan untuk menghitung kinerja atau tingkat kebenaran proses klasifikasi. Dengan confusion matrix dapat dianalisa seberapa baik classifier dapat mengenali record dari kelaskelas yang berbeda. Tabel confusion matrix ditunjukkan pada tabel berikut ini :

TABEL I

CONFUSION MATRIX

\begin{tabular}{|c|c|c|}
\hline Kelas & Terklasifikasi Positive & Terklasifikasi Negatif \\
\hline Positive & TP (True Positive) & FN (False Negative) \\
\hline Negative & FP (False Positive) & TN (True Negative) \\
\hline
\end{tabular}

Keterangan:

- TP adalah True Positive, yaitu jumlah data positif yang terklasifikasi dengan benar oleh sistem.

- $\quad$ TN adalah True Negative, yaitu jumlah data negatif yang terklasifikasi dengan benar oleh sistem.
- $\quad$ FN adalah False Negative, yaitu jumlah data negatif namun terklasifikasi salah oleh sistem.

- $\quad$ FP adalah False Positive, yaitu jumlah data positif namun terklasifikasi salah oleh system

Berdasarkan nilai True Negative (TN), False Negative (FN) , dan True Positive (TP) dapat diperoleh nilai akurasi, presisi dan recal;

1. Nilai akurasi menggambarkan seberapa akurat sistem dapat mengklasifikasikan data secara benar. Dengan kata lain, nilai akurasi merupakan perbandingan antara data yang terklasifikasi benar dengan keseluruhan data. Nilai akurasi dapat diperoleh dengan persamaan berikut.

$$
\text { Akurasi }=\frac{T P+T N}{T P+T N+F P+F N} * 100 \%
$$

2. Nilai presisi menggambarkan jumlah data kategori positif yang diklasifikasikan secara benar dibagi dengan total data yang diklasifikasi positif. Presisi dapat diperoleh dengan persamaan berikut.

$$
\text { Presisi }=\frac{T P}{F P+T P} * 100 \%
$$

3. Nilai recal lmenunjukkan berapa persen data kategori positif yang terklasifikasikan dengan benar oleh sistem. Presisi dapat diperoleh dengan persamaan berikut.

$$
\text { Recall }=\frac{T P}{F N+T P} * 100 \%
$$

\section{HASIL DAN PEMBAHASAN}

\section{A. Perhitungan MOORA}

1. Kriteria

Tahap awal dari menyelesaikan studi kasus ini adalah menganalisa kriteria sebagai dasar proses dilakukannya seleksi. Adapun kriteria yang digunakan adalah Harga (C1), Desain (C2), Kualitas (C3), Pelayanan (C4), Pengiriman (C5). Contoh datadari kriteria tersebut adalah:

TABEL II

DATA KRITERIA

\begin{tabular}{|l|l|l|l|}
\hline Kriteria & Keterangan & Bobot & Jenis \\
\hline C1 & Harga & $25 \%$ & Cost \\
\hline C2 & Desain & $25 \%$ & Benefit \\
\hline C3 & Kualitas & $25 \%$ & Benefit \\
\hline C4 & Pelayanan & $10 \%$ & Benefit \\
\hline
\end{tabular}




\begin{tabular}{|l|l|l|l|}
\hline C5 & Pengiriman & $15 \%$ & Cost \\
\hline
\end{tabular}

Kriteria yang memakai penilaian bukan nilai angka akan di sesuaikan dengan skala penilaian seperti di bawah ini:

$\begin{array}{ll}\text { Sangat Baik } & =4 \\ \text { Baik } & =3 \\ \text { Cukup } & =2 \\ \text { Kurang } & =1\end{array}$

Kriteria harga akan di sesuaikan dengan skala penilaian seperti di bawah ini:
Rp. 53.000 - Rp. $55.999=4$
Rp. $56.000-$ Rp. $58.999=3$
Rp. $59.000-$ Rp. $61.999=2$
$\geq$ Rp. $62.000 \quad=1$

Kriteria lama pengiriman akan di sesuaikan dengan skala penilaian seperti di bawah ini:

Pengiriman 1 har $\mathrm{i}=4$

Pengiriman 2 hari $\quad=3$

Pengiriman 3 hari $\quad=2$

Pengiriman $\geq 4$ hari $\quad=1$

2. Pemberian Nilai Tiap Alterantif

Data Penilaian Alternatif berdasarkan kriteria di atas dapatdilihat pada tabel berikut :

TABEL III

PEMBERIAN NILAI TIAP ALTERNATIF

\begin{tabular}{|l|l|l|l|l|l|}
\hline Alternatif & C1 & C2 & C3 & C4 & C5 \\
\hline A1 & Rp. 58.900 & 3 & 3 & 3 & 1 hari \\
\hline A2 & Rp. 60.000 & 4 & 4 & 3 & 3 hari \\
\hline A3 & Rp. 55.000 & 3 & 3 & 3 & 4 hari \\
\hline A4 & Rp. 59.800 & 4 & 3 & 3 & 3 hari \\
\hline A5 & Rp. 60.000 & 4 & 4 & 2 & 2 hari \\
\hline A6 & Rp. 55.000 & 3 & 3 & 3 & 3 hari \\
\hline A7 & Rp. 56.000 & 3 & 2 & 2 & 2 hari \\
\hline
\end{tabular}

3. Langkah penyelesaian metode MOORA:

a. Matriks keputusan Xij

TABEL IV

MATRIKS KEPUTUSAN

\begin{tabular}{|l|l|l|l|l|}
\hline 3 & 3 & 3 & 3 & 4 \\
\hline 2 & 4 & 4 & 3 & 2 \\
\hline 4 & 3 & 3 & 3 & 1 \\
\hline
\end{tabular}

\begin{tabular}{|l|l|l|l|l|}
\hline 1 & 4 & 3 & 3 & 2 \\
\hline 1 & 4 & 4 & 2 & 3 \\
\hline 4 & 3 & 3 & 3 & 2 \\
\hline 2 & 3 & 2 & 2 & 3 \\
\hline
\end{tabular}

b. Matriks kinerja ternormalisasi

Kriteria 1 (C1)

$$
\begin{aligned}
& =\sqrt{3^{2}+2^{2}+4^{2}+1^{2}+1^{2}+4^{2}+2^{2}} \\
& =7.141 \\
& A_{11}=3 / 7.141=0.4201 \\
& A_{12}=2 / 7.141=0.2800 \\
& A_{13}=4 / 7.141=0.5601 \\
& A_{14}=1 / 7.141=0.1400 \\
& A_{15}=1 / 7.141=0.1400 \\
& A_{16}=4 / 7.141=0.5601 \\
& A_{17}=2 / 7.141=0.2800
\end{aligned}
$$

Maka dapat dilihat matriks ternormalisasi berikut, yaitu :

TABEL $\mathrm{V}$

MATRIKS NORMALISASI

\begin{tabular}{|l|l|l|l|l|}
\hline 0.4201 & 0.3273 & 0.3535 & 0.412 & 0.5835 \\
\hline 0.2800 & 0.4364 & 0.4714 & 0.412 & 0.2197 \\
\hline 0.5601 & 0.3273 & 0.3535 & 0.412 & 0.1458 \\
\hline 0.1400 & 0.4364 & 0.3535 & 0.412 & 0.2197 \\
\hline 0.1400 & 0.4364 & 0.4714 & 0.2747 & 0.4376 \\
\hline 0.5601 & 0.3273 & 0.3535 & 0.412 & 0.2197 \\
\hline 0.2800 & 0.3273 & 0.2357 & 0.2747 & 0.4376 \\
\hline
\end{tabular}

Selanjutnya menghitung matriks ternormalisasi terbobot :

$$
\begin{aligned}
\mathrm{C} 1=\mathrm{A}_{11} & =0.25 \times 0.4201=0.105 \\
\mathrm{~A}_{12} & =0.25 \times 0.2800=0.07 \\
\mathrm{~A}_{13} & =0.25 \times 0.5601=0.14 \\
\mathrm{~A}_{14} & =0.25 \times 0.1400=0.035 \\
\mathrm{~A}_{15} & =0.25 \times 0.1400=0.035 \\
\mathrm{~A}_{16} & =0.25 \times 0.5601=0.14 \\
\mathrm{~A}_{17} & =0.25 \times 0.2800=0.07
\end{aligned}
$$

Maka hasilnya dapat dilihat pada matriks di bawah ini :

TABEL VI

HASIL MATRIKS TERNORMALISASI TERBOBOT

\begin{tabular}{|l|l|l|l|l|}
\hline 0.0105 & 0.0818 & 0.0883 & 0.0412 & 0.0875 \\
\hline
\end{tabular}




\begin{tabular}{|c|c|c|c|c|}
\hline 0.07 & 0.1091 & 0.1178 & 0.0412 & 0.0437 \\
\hline 0.014 & 0.0818 & 0.0883 & 0.0412 & 0.0218 \\
\hline 0.035 & 0.1091 & 0.0883 & 0.0412 & 0.0437 \\
\hline 0.035 & 0.1091 & 0.1178 & 0.0274 & 0.0656 \\
\hline 0.014 & 0.0818 & 0.0883 & 0.0412 & 0.0437 \\
\hline 0.07 & 0.0818 & 0.0589 & 0.0274 & 0.0656 \\
\hline
\end{tabular}

Selanjutnya pencarian nilai Yi seperti berikut :

TABEL VII

PENCARIAN NILAI Yi

\begin{tabular}{|c|l|l|c|}
\hline Alternatif & $\operatorname{Max}(\mathrm{C} 2+\mathrm{C} 3+\mathrm{C} 4)$ & $\operatorname{Min}(\mathrm{C} 1+\mathrm{C} 5)$ & Yi = Max-Min \\
\hline A1 & $\begin{array}{l}0.0818+0.0883 \\
+0.0412\end{array}$ & $0.0105+0.0875$ & 0.0188 \\
\hline A2 & $\begin{array}{l}0.1091+0.1178 \\
+0.0412\end{array}$ & $0.07+0.0437$ & 0.1543 \\
\hline A3 & $\begin{array}{l}0.0818+0.0883 \\
+0.0412\end{array}$ & $0.014+0.0218$ & 0.0495 \\
\hline A4 & $\begin{array}{l}0.1091+0.0883 \\
+0.0412\end{array}$ & $0.035+0.0437$ & 0.1599 \\
\hline A5 & $\begin{array}{l}0.1091+0.1178 \\
+0.0274\end{array}$ & $0.035+0.0656$ & 0.1537 \\
\hline A6 & $\begin{array}{l}0.0818+0.0883 \\
+0.0412\end{array}$ & $0.014+0.0437$ & 0.0276 \\
\hline A7 & $\begin{array}{l}0.0818+0.0593+ \\
0.0274\end{array}$ & $0.07+0.0656$ & 0.0325 \\
\hline
\end{tabular}

Adapun hasil perangkingan seperti berikut :

TABEL VIII

PERANGKINGAN

\begin{tabular}{|c|c|c|}
\hline Alternatif & Yi & Rangking \\
\hline A4 & 0.1599 & 1 \\
\hline A2 & 0.1543 & 2 \\
\hline A5 & 0.1537 & 3 \\
\hline A3 & 0.0495 & 4 \\
\hline A7 & 0.0325 & 5 \\
\hline A6 & 0.0276 & 6 \\
\hline
\end{tabular}

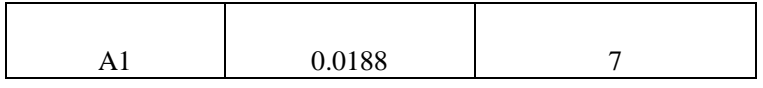

Dari peroses tersebut maka dapat di simpulkan bahwa A4 adalah alternatif terbaik.

\section{B. Pengujian Sistem}

Pengujian yang dilakukan yaitu pengujian dengan menggunakan confusion matrix untuk mendapatkan nilai keakuratan. Pada pengujian ini dilakukan dengan membandingkan hasil dari perhitungan manual dan perhitungan sistem untuk mencari kesesuaian. Data tersebut dikatakan sesuai apabila hasil perekomendasi dari sistem maupun manual sama. Pada pengujian ini menggunakan data supplier sebanyak 30 data, dan pada setiap proses perhitunganya akan dihitung jumlah True Positive (TP), True Negative(TN), false Positive(FP) dan false Negative(FN).

TABEL IX

HASIL AKURASI CONFUSION MATRIX

\begin{tabular}{|c|c|c|}
\hline Kriteria Pengujian & Jumlah & Hasil Pengujian Akurasi \\
\hline True Positive (TP) & 24 & \multirow{5}{*}{$\begin{array}{l}\text { Rumus: } \\
(\mathrm{TP}+\mathrm{TN}) /(\mathrm{TP}+\mathrm{TN}+\mathrm{FP}+\mathrm{FN}) \\
:(24+0) /(24+0+0+6) * 100 \% \\
:(24 / 30) * 100 \% \\
: 0.8 * 100 \% \\
: 80 \%\end{array}$} \\
\hline True Negative (TN) & 0 & \\
\hline False Positive (FP) & 0 & \\
\hline False Negative (FN) & 6 & \\
\hline TOTAL & 30 & \\
\hline
\end{tabular}

Dari tabel hasil pengujian diatas dapat dilihat bahwa nilai Accuracy / kesesuaian dari sistem yaitu sebesar $80 \%$.

\section{KESIMPULAN}

Berdasarkan hasil penelitian yang telah dilakukan maka dapat dibuat kesimpulan sebagai berikut:

1. Sistem pendukung keputusan yang dibuat dapat membantu dalam memilih supplier terbaik pada Toko Yani Kain. Perancangan aplikasi menggunakan diagram UML(Use Case Diagram, Activity Diagram, Class Diagram, dan Sequence Diagram) dan ERD untuk perancangan basis data.

2. Metode MOORA dapat diimplementasikan sebagai sistem pendukung keputusan pemilihan supplier di Yani Kain. Dalam penelitian ini terdapat 5 kriteria yang ada, yaitu desain, harga, kualitas, pengiriman dan pelayanan. Metode perhitungan MOORA memiliki 8 tahapan, yaitu pendefinisian kriteria, pemeberian nilai tiap alternatif, perubahan niali tiap alternatif, matrik keputusan, matrik normalisasi, matrik normalisasi terbobot, pencaria nilai Yi, dan Perangkigan. 
3. Setelah dilakukan perhitungan terhadap 30 sample data supplier, dilakukan pengujian menggunakan confusion matrix dengan hasil akurasi sebesar $80 \%$.

\section{REFERENSI}

[1] Chairul Fadlan, Agus Perdana Windarto , Irfan Sudahri Damanik. (2019). Penerapan Metode MOORA pada Sistem Pemilihan Bibit Cabai (Kasus: Desa Bandar Siantar Kecamatan Gunung Malela).

[2] Chakraborty, S. (2011). Applications of the MOORA method for decision making in anufacturing environment. Int. J. Adv. Manuf. Technol., vol. 54, no. 9-12, pp. 1155-1166, 2011.

[3] Chandra Frenki Sianturi, Megawati Tondang, Sarmauli Batubara, Andysah P U Siahaan. (2018). Sistem Pendukung Keputusan Pemilihan Supplier Barang Lemari Menerapkan Metode MOORA.

[4] D. Assrani, N. Huda, R. Sidabutar, I. Saputra, and O. K. Sulaiman. (2018). Penentuan Penerima Bantuan Siswa Miskin Menerapkan Metode Multi Objective Optimization on The Basis of Ratio Analysis (MOORA)," Penentuan Penerima Bantu. Siswa Miskin Menerapkan Metod. Multi Object. Optim. Basis Ratio Anal., vol. 5, no. 2407-389X (Media Cetak), pp. 1-5, 2018.

[5] Hutahaean, J. (2014). Konsep Sistem Informasi : CV BUDI UTAMA.

[6] Kristanto, A. (2008). Perancangan Sistem Informasi dan Aplikasinya : Konsep Dasar Sistem, hal. 1-2.

[7] Laudia Olivianita, Ekojono, Rudy Ariyanto. (2016). Sistem Pendukung Keputusan Kelayakan Hasil Cetakan Buku Menggunakan Metode MOORA.

[8] Ma'ruf. (2016). Pemilihan Supplier Menggunakan Metode Topsis Pada Perusahaan Furniture. Pros. Semin. Nas. Ekon. dan Bisnis Call Papaer FEB UMSIDA 2016, pp. 287-304, 2016.

[9] Nofriansyah, D. (2014). Konsep Data Mining Vs Sistem Pendukung Keputusan.

[10] Rossa A.S,dan M. Shalahuddin. (2013). Rekayasa Perangkat Lunak Terstruktur dan Berorientasi Objek. Bandung: Informatika

[11] Sri Wardani, Iin Parlina, Ahmad Revi . (2018). Analisis Perhitungan Metode MOORA dalam Pemilihan Supplier Bahan Bangunan di Toko Megah Grancindo Jaya.
[12] Syaiful Rokhman, Imam Fahrur Rozi ,Rosa Andrie Asmara . (2017). Pengembangan Sistem Penunjang Keputusan Penentuan UKT Mahasiswa dengan Menggunakan Metode MOORA Studi Kasus Politeknik Negeri Malang.

[13] Turban , Efraim \& Aronson, Jay E. (2001). Decision Support Systems and Intelligent Systems. 6th edition. Prentice Hall: Upper Saddle River, NJ. 